\title{
JUKMAS
}

Jurnal Untuk Masyarakat Sehat (JUKMAS)

e-ISSN : 2715-7687

Vol. 5, No. 1 April 2021

P-ISSN : 2715-8748

\section{Faktor Yang Berhubungan Dengan Status Gizi Anak Pra Sekolah}

\author{
Izattul Azijah , Asyifa Robiatul Adawiyah \\ Fakultas Ilmu Kesehatan Universitas Respati Indonesia \\ iza@urindo.ac.id
}

\begin{abstract}
Abstrak
Salah satu indikator keberhasilan pembangunan adalah dengan melihat status gizi. Terganggunya pertumbuhan fisik dan kecerdasan pada anak disebabkan oleh keadaan kurang gizi. Tujuan Penelitian adalah mengetahui faktor dominan yang berhubungan dengan Status Gizi Anak Pra Sekolah. Populasi dalam penelitian adalah seluruh anak yang belajar di TK Mutiara 17 Agustus yang berjumlah 59 orang. Sampel dalam penelitian diambil menggunakan teknik total sampling. Penelitian ini dianalisis secara univariat, bivariat dengan uji chi square dan multivariat menggunakan regresi logistik. Berdasarkan hasil analisis univariat didapatkan hasil pengukuran umur, berat badan, dan tinggi badan pada bulan Juni didapatkan bahwa 29 anak $(49,15 \%)$ dari 59 anak mempunyai status gizi gemuk-obesitas, dengan rentang umur responden berkisar antara $48-82$ bulan, berat badan $15-41 \mathrm{~kg}$, dan tinggi badan $99-135$ $\mathrm{cm}$, status gizi berdasarkan IMT/U didapatkan hasil rentang z-score -2,21 - 4,86 dengan jenis kelamin 32 laki-laki $(54,2 \%)$ dan 27 perempuan $(45,8 \%)$. Hasil analisis multivariat didapatkan terdapat 3 variabel yang mempunyai $p$ value $<0,05$ yaitu pendidikan ibu ( $p$ value $=0,027$ ), cara penyusunan menu ( $p$ value $=0,015)$, dan cara pemberian menu ( $p$ value $=0,023$ ). Cara pemberian menu mempunyai nilai OR yang paling besar yaitu sebesar 69,38 . Kesimpulan dari penelitian yang telah dilakukan adalah cara pemberian makan, cara penyusunan menu, dan Pendidikan ibu merupakan prediktor dari status gizi anak prasekolah. Diharapkan bagi ibu untuk mengikuti penyuluhan tentang status gizi anak dan Sekolah bekerjasama dengan pihak puskesmas setempat untuk dilakukan promosi atau edukasi tentang gizi pada anak prasekolah.
\end{abstract}

Kata Kunci : : Pendidikan, penyusunan menu, pemberian menu, status gizi

\begin{abstract}
One indicator of development success is by looking at nutritional status. The disruption of physical growth and intelligence in children is caused by malnutrition. The research objective was to determine the dominant factors related to the nutritional status of pre-school children. The population in this study were all 59 children who studied at Mutiara Kindergarten 17 August. The sample in this study was taken using total sampling technique. This research was analyzed by univariate, bivariate with chi square test and multivariate using logistic regression. Based on the results of univariate analysis, it was found that the results of measurements of age, weight, and height in June showed that 29 children (49.15\%) of 59 children had nutritional status of obesity, with a respondent age range between $48-82$ months, weight body $15-41 \mathrm{~kg}$, and height $99-135 \mathrm{~cm}$, nutritional status based on BMI / U obtained z-score ranges of $-2.21-4.86$ with the sexes of 32 men (54.2\%) and 27 women (45.8\%). The results of the multivariate analysis showed that there were 3 variables that had $p$ value $<0.05$, namely maternal education ( $p$ value $=0.027$ ), how to prepare menus ( $p$ value $=$ 0.015 ), and how to provide menus ( $p$ value $=0.023$ ). The method of giving the menu has the greatest $O R$ value, which is equal to 69.38 . The conclusion from the research that has been
\end{abstract}

http://ejournal.urindo.ac.id/index.php/jukmas

Article History :

Submitted 12 Desember 2020, Accepted 28 April 2021, Published 30 April 2021 
done is how to feed, how to prepare menus, and mother's education are predictors of the nutritional status of preschool children. It is hoped that mothers will attend counseling on the nutritional status of children and schools in collaboration with the local health center to carry out promotion or education about nutrition in preschool children.

Keywords: Education, menu preparation, menu delivery, nutritional status

\section{PENDAHULUAN}

Golden Age adalah usia yang
sangat penting bagi pertumbuhan dan
perkembangan individu yang berada pada
masa kanak-kanak antara usia 1-6
tahun. Suatu proses bertambahnya
struktur, fungsi, dan kemampuan manusia
yang lebih kompleks dalam pola yang
teratur, sebagai hasil dari proses
pematangan disebut dengan
perkembangan. ${ }^{1}$

Masa lima tahun pertama kehidupan merupakan masa yang sangat peka terhadap lingkungan dan masa ini berlangsung sangat pendek dan tidak bisa diulang kembali, masa ini sering juga disebut masa keemasan (Golden Period), jendela kesempatan (window of opportunity) dan masa kritis. ${ }^{2}$

Pertumbuhan fisik dan psikologis bertumbuh dengan pesat pada anak usia prasekolah. Salah satu yang berperan penting dalam proses pertumbuhan dan perkembangan adalah pola makan anak, oleh karena itu diperlukan makanan yang banyak mengandung zat gizi. Pertumbuhan dan perkembangan akan terhambat Jika pola makan anak tidak tercapai dengan baik. Pola pemberian makan orang tua mempengaruhi status kesehatan anak usia prasekolah. Pola pemberian makan yang kurang tepat dapat menyebabkan kegemukan, keparahan penyakit, gangguan kecerdasan intelektual, anemia perawakan pendek peningkatan risiko angka kematian dan angka kesakitan pada anak. ${ }^{3}$

Pola pemberian makan yang kurang baik dapat mempengaruhi status gizi balita tersebut, sehingga masa balita sering dinyatakan sebagai masa kritis untuk optimalisasi pertumbuhan dan perkembangan otak yang sangat dipengaruhi oleh pola asuh orang tua, salah satunya dalam pola pemberian makan sebagai pintu masuk pemenuhan berbagai kebutuhan unsur zat gizi. ${ }^{4}$

Salah satu indikator keberhasilan pembangunan adalah dengan melihat status gizi. Terganggunya pertumbuhan fisik dan kecerdasan pada anak disebabkan oleh keadaan kurang gizi. ${ }^{5}$

Status gizi anak balita dipengaruhi oleh beberapa faktor antara lain pendidikan ibu, pekerjaan ibu, jumlah anak, pengetahuan dan pola asuh ibu 
serta kondisi ekonomi orang tua secara keseluruhan. Keadaan tubuh sebagai akibat dari pemakaian, penyerapan, dan penggunaan makanan disebut dengan status gizi. Selain itu status gizi juga dapat diartikan sebagai ekspresi dari keadaan keseimbangan dalam bentuk variabel tertentu, atau perwujudan dari status tubuh yang berhubungan dengan gizi dalam bentuk variabel tertentu. ${ }^{6}$

Hasil studi pendahuluan status gizi pada total 58 anak prasekolah yang yang diukur pada tanggal 29 Juli 2019 terbagi menjadi dua kelompok antara yang berusia di bawah sampai dengan 5 tahun (34 anak) dan berusia diatas 5 tahun ( 24 anak) di TK Mutiara 17 Agustus Kota Bekasi menunjukkan bahwa Status Gizi anak dibawah sampai dengan 5 tahun berdasarkan Indeks BB/U didapatkan bahwa $15 \%$ anak berada dalam $z$-score -3 SD sampai dengan $<-2$ SD artinya anak yang berada pada z-score tersebut merupakan anak dalam status gizi kurang (underweight), 5\% anak berada dalam rentang z-score <-3 SD artinya 5\% anak berada dalam status gizi buruk (severely underweight), dan $\pm 10 \%$ anak berada pada z-score >2 SD artinya 10\% anak berada dalam status gizi lebih. Berdasarkan Indeks TB/U didapatkan bahwa 5\% anak berada dalam z-score -3 SD sampai dengan <-2 SD artinya $5 \%$ anak yang berada pada $z$-score tersebut merupakan anak dengan stunting, $3 \%$ anak berada dalam z-score -3 SD artinya $3 \%$ stunting berat, dan $10 \%$ anak berada dalam z-score >2 SD artinya 10\% anak memiliki status tinggi badan yang tinggi. Berdasarkan Indeks BB/TB didapatkan bahwa $10 \%$ anak berada dalam z-score -3 SD sampai dengan <-2 SD artinya anak yang berada pada z-score tersebut merupakan anak dengan proporsional badan kurus (wasted), 5\% anak berada dalam z-score <-3 SD artinya 5\% anak berada dalam status gizi dengan proporsional badan sangat kurus (severely wasted), dan $8 \%$ anak berada dalam zscore $>2$ SD artinya $8 \%$ anak berada dalam status gizi dengan proporsional badan gemuk. Status Gizi anak diatas 5 tahun berdasarkan Indeks IMT/U (Indeks Massa Tubuh menurut Umur) didapatkan bahwa $12 \%$ anak berada pada z-score -3 SD sampai dengan <-2 SD artinya $12 \%$ anak yang berada pada z-score tersebut memiliki status gizi dengan proporsional badan kurus, $10 \%$ anak berada pada zscore <-3 SD artinya $10 \%$ anak yang berada pada z-score tersebut memiliki status gizi dengan proporsional badan sangat kurus, $12 \%$ anak berada pada z-score 1SD sampai dengan < 2SD artinya 12\% anak yang berada pada z-score tersebut memiliki status gizi dengan proporsional badan gemuk, dan $10 \%$ anak berada pada z-score 
$<3$ SD artinya $10 \%$ anak yang berada pada z-z-score tersebut memiliki status gizi dengan proporsional badan obesitas.

\section{METODE}

Penelitian ini dianalisis secara univariat, bivariat dengan uji chi square dan multivariat menggunakan regresi logistik. Populasi dalam penelitian ini adalah seluruh anak yang belajar di TK Mutiara 17 Agustus Bekasi tahun ajaran 2019-2020 yang berjumlah 59 orang yang diambil secara keseluruhan atau menggunakan teknik total sampling. Penelitian ini dilakukan dengan cara mengukur $\mathrm{BB}, \mathrm{TB}$, dan umur responden dari bulan januari-juni tahun 2020, tetapi hasil status gizi IMT/U bulan Juni saja yang dipakai sebagai analisis. Penelitian ini menggunakan analisis data univariat untuk mengetahui distribusi frekuensi. Analisis multivariat menggunakan regresi logistik. Variabel independen adalah Jenis kelamin, usia ibu, pendidikan ibu, jumlah anak, jumlah anggota keluarga, riwayat ASI eksklusif, Anak sakit selama Januari sampai dengan Juni, pengetahuan ibu, Pola Pemberian Makan, dan FFQ (Food Frequency Questionnaire). Variabel pengetahuan ibu, terdiri dari 15 pertanyaan tentang status gizi, zat gizi, dan gizi seimbang. Variabel pola pemberian makan terbagi menjadi 4 domain, total 24 pernyataan, dengan pilihan jawaban selalu, sering, kadang-kadang, tidak pernah. 4 domain variabel tersebut adalah (1) cara penyusunan menu 5 pernyataan, yaitu tentang bagaimana ibu responden menyusun menu dengan memperhatikan komposisi zat gizi, penyusunan menu berdasarkan kesenangan anak, dan perhitungan kebutuhan gizi anak dengan hasil skor min-max 5-20; (2) cara olah menu 5 pernyataan, yaitu tentang bagaimana cara pengolahan menu yang ibu responden lakukan, penggunaan komposisi bumbu, cara pengolahan sayuran dengan hasil skor min-max 5-20; (3) cara saji menu 5 pernyataan, yaitu tentang bagaimana ibu responden menyajikan makanan dengan bentuk yang menarik bagi anak, menentukan porsi makanan anak, pembuatan variasi dan kombinasi warna pada makanan dengan hasil skor min-max 5-20; dan (4) cara pemberian menu 9 pernyataan, yaitu bagaimana ibu responden memberikan menu makanan secara teratur, memperhatikan tentang gizi seimbang, mengatur antara aktivitas anak dan jadwal makan dengan hasil skor minmax 9-36. Variabel FFQ terdiri dari konsumsi makanan pokok, lauk hewani, kacang-kacangan, sayur-sayuran, buahbuahan, susu dan olahannya, jajanan dan junkfood, Softdrink dan minuman manis, serta multivitamin. Variabel dependen 
dalam penelitian ini adalah hasil pengukuran umur, berat badan, dan tinggi badan bulan Juni 2020 yang diukur menjadi status gizi IMT/U dengan cut of point sudah dikelompokan kembali berdasarkan usia anak dibawah 5 tahun dan diatas 5 tahun. Pengukuran IMT/U menggunakan software WHO Anthro Plus dengan rentang usia yg bisa digunakan mulai dari 2 tahun sampai dengan 18 tahun. Kriteria Inklusi dalam penelitian ini adalah : Anak prasekolah yang mengikuti pengukuran setiap bulan dan orang tua atau wali anak bersedia mengikuti penelitian.

\section{HASIL DAN PEMBAHASAN}

Berdasarkan hasil pengukuran umur, berat badan, dan tinggi badan pada bulan Juni didapatkan bahwa 29 anak $(49,15 \%)$ dari 59 anak mempunyai status gizi gemukobesitas, dengan rentang umur responden berkisar antara $48-82$ bulan, berat badan $15-41 \mathrm{~kg}$, dan tinggi badan $99-135 \mathrm{~cm}$, status gizi berdasarkan IMT/U didapatkan hasil rentang $z$-score $-2,21-4,86$ dengan jenis kelamin 32 laki-laki (54,2\%) dan 27 perempuan $(45,8 \%)$, pendidikan terakhir 43 ibu responden (72,9\%) adalah Perguruan tinggi, data pengetahuan ibu tentang gizi diperoleh dari jumlah skor kemudian di konversi menjadi persentase dari skala 0 $100 \%$ selanjutnya dikategorikan menjadi pengetahuan kurang dan pengetahuan baik. Data yang didapatkan yaitu berupa variabel numerik, sehingga sebelum di kategorikan akan dilakukan uji normalitas data terlebih dahulu menggunakan uji Shapiro Wilk dan hasilnya data tidak berdistribusi normal yang ditujukan oleh nilai $\mathrm{p}$ sebesar $0,000<\alpha(0,05)$ maka digunakan median sebagai ukuran pemusatan minimum-maksimum sebagai ukuran penyebaran. Diperoleh nilai median sebesar $80 \%$ dengan interpretasi jika benar $<80 \%$ disebut pengetahuan kurang sedangkan $\geq 80 \%$ disebut pengetahuan baik, berdasarkan pengetahuan ibu didapatkan rentang $20-100 \%$ benar. Variabel pola pemberian makan yang terbagi menjadi (1) cara penyusunan menu; (2) cara olah menu; (3) cara saji menu; dan (4) cara pemberian menu dengan Data yang didapatkan yaitu berupa variabel numerik, sehingga sebelum di kategorikan akan dilakukan uji normalitas data terlebih dahulu menggunakan uji Shapiro Wilk dan hasilnya data tidak berdistribusi normal yang ditujukan oleh nilai $\mathrm{p}$ sebesar $0,000<\alpha(0,05)$ maka digunakan median sebagai ukuran pemusatan minimum-maksimum sebagai ukuran penyebaran. Domain (1) cara penyusunan menu terbagi menjadi kategori skor <13 (makanan kurang bervariasi) dan $\geq 13$ (makanan bervariasi); (2) cara olah menu terbagi menjadi 
kategori skor $<13$ (kurang menjaga kualitas olahan makanan) dan $\geq 13$ (baik dalam menjaga kualitas makanan); (3) cara saji menu terbagi menjadi kategori skor $<12$ (penyajian makanan monoton) dan $\geq 13$ (penyajian makanan menarik); dan (4) cara pemberian menu terbagi menjadi kategori skor <24 (cara \& waktu pemberian makanan kurang teratur) dan $\geq 24$ (cara \& waktu pemberian makanan teratur). Hasil didapatkan bahwa 13 (52,5\%) ibu responden menyusun menu dengan makanan yang bervariasi, $38(64,4 \%)$ ibu responden mengolah menu makanan dengan baik dan menjaga kualitas makanannya, 33 (55,9\%) ibu responden menyajikan menu makanan dengan bentuk yang menarik, dan $32(54,2 \%)$ responden memberikan menu makanan dengan cara \& waktu pemberian yang teratur. Ratarata total konsumsi harian responden melalui FFQ perhari adalah 21 jenis makanan dan minuman.

Tabel 1

Gambaran Status Gizi TK Mutiara 17 Agustus bulan Januari-Juni 2020

\begin{tabular}{ccccccc}
\hline & Januari & Februari & Maret & April & Mei & Juni \\
\hline Umur & $43-77$ & $44-78$ & $44-79$ & $45-80$ & $46-81$ & $48-82$ \\
& bulan & bulan & bulan & bulan & bulan & bulan \\
\hline BB & $10-37 \mathrm{~kg}$ & $12-35,5 \mathrm{~kg}$ & $12-38 \mathrm{~kg}$ & $13-40 \mathrm{~kg}$ & $14-40 \mathrm{~kg}$ & $15-41 \mathrm{~kg}$ \\
\hline TB & $94-128,5$ & $95-129 \mathrm{~cm}$ & $95-130$ & $97-132$ & $98-133$ & $99-135$ \\
& $\mathrm{~cm}$ & & $\mathrm{~cm}$ & $\mathrm{~cm}$ & $\mathrm{~cm}$ & $\mathrm{~cm}$ \\
\hline z-score BB/U & $-4,18-3,9$ & $-3,04-3,8$ & $-3,23-$ & $-2,06-$ & $-2,11-$ & $-1,72-$ \\
& & & 3,92 & 4,25 & 4,15 & 4,25 \\
\hline Gizi buruk & $\pm 7 \%$ & $\pm 7 \%$ & $\pm 5 \%$ & $\pm 2 \%$ & - & - \\
\hline Gizi kurang & $\pm 13 \%$ & $\pm 15 \%$ & $\pm 13 \%$ & $\pm 12 \%$ & $\pm 8 \%$ & $\pm 4 \%$ \\
\hline Gizi lebih & $\pm 12 \%$ & $\pm 13 \%$ & $\pm 15 \%$ & $\pm 17 \%$ & $\pm 18 \%$ & $\pm 22 \%$ \\
\hline z-score TB/U & $-3,4-2,14$ & $-3,28-2,26$ & $-3,36-$ & $-3,04-$ & $-2,92-2,6$ & $-2,8-$ \\
& & & 2,41 & 2,51 & & 2,87 \\
\hline Very stunted & $\pm 2 \%$ & $\pm 2 \%$ & $\pm 2 \%$ & $\pm 1 \%$ & $\pm 1 \%$ & $\pm 1 \%$ \\
\hline stunting & $\pm 10 \%$ & $\pm 5 \%$ & $\pm 6 \%$ & $\pm 5 \%$ & $\pm 4 \%$ & $\pm 4 \%$ \\
\hline tinggi & $\pm 8 \%$ & $\pm 9 \%$ & $\pm 11 \%$ & $\pm 12 \%$ & $\pm 12 \%$ & $\pm 16 \%$ \\
\hline z-score IMT/U & $-3,98-4,77$ & $-3,05-4,72$ & $-2,87-$ & $-2,23-$ & $-2,39-$ & $-2,21-$ \\
\hline
\end{tabular}


Jurnal Untuk Masyarakat Sehat (JUKMAS)

\begin{tabular}{ccccccc}
\hline & & & 4,99 & 5,24 & 4,83 & 4,86 \\
\hline Sangat Kurus & $\pm 8 \%$ & $\pm 5 \%$ & $\pm 5 \%$ & $\pm 2 \%$ & $\pm 2 \%$ & - \\
\hline Kurus & $\pm 14 \%$ & $\pm 14 \%$ & $\pm 11 \%$ & $\pm 11 \%$ & $\pm 7 \%$ & $\pm 6 \%$ \\
\hline Gemuk & $\pm 13 \%$ & $\pm 15 \%$ & $\pm 18 \%$ & $\pm 17 \%$ & $\pm 18 \%$ & $\pm 20 \%$ \\
\hline Obesitas & $\pm 12 \%$ & $\pm 13 \%$ & $\pm 16 \%$ & $\pm 17 \%$ & $\pm 13 \%$ & $\pm 22 \%$ \\
\hline
\end{tabular}

Tabel 2

Hasil Analisis Univariat (IMT/U Juni)

No. Variabel Jumlah Persentase (\%)

1. Perubahan IMT/U dari bulan Januari ke Juni

$\begin{array}{lll}\text { Berkurang } & 16 & 27,1 \\ \text { Bertambah } & 43 & 72,9\end{array}$

2. Jenis Kelamin

$\begin{array}{lll}\text { Perempuan } & 27 & 45,8 \\ \text { Laki-laki } & 32 & 54,2\end{array}$

3. Usia Ibu

$\begin{array}{lll}<36.10 \text { tahun } & 34 & 57,6 \\ \geq 36.10 \text { tahun } & 25 & 42,4\end{array}$

4. Pendidikan Ibu

SMA kebawah

$16 \quad 27,1$

Perguruan Tinggi

$43 \quad 72,9$

5. Jumlah anak

$\begin{array}{lll}>2 \text { anak } & 4 & 6,8 \\ \leq 2 \text { anak } & 55 & 93,2\end{array}$

6. Jumlah Anggota keluarga

$\begin{array}{lll}>4 \text { anggota keluarga } & 13 & 22 \\ \leq 4 \text { anggota keluarga } & 46 & 78\end{array}$

\section{ASI Eksklusif}

$\begin{array}{lll}<6 \text { bulan } & 20 & 33,9 \\ \geq 6 \text { bulan } & 39 & 66,1\end{array}$

8. Anak Sakit (Januari-Juni)

Ya

$5 \quad 8,5$


Tidak

54

91,5

9. Pengetahuan Ibu
$<80 \%$
28
47,5
$\geq 80 \%$
31
52,5

POLA PEMBERIAN MAKAN

10. Cara Penyusunan Menu

$\begin{array}{lll}<13 \text { (Kurang variatif) } & 28 & 47,5 \\ \geq 13 \text { (makanan bervariasi) } & 31 & 52,5\end{array}$

11. Cara Olah Menu

< 13 (kurang menjaga kualitas olahan $21 \quad 35,6$

makanan)

$\geq 13$ baik dalam menjaga kualitas makanan $38 \quad 64,4$

12. Cara Saji Menu
$<12$ penyajian monoton
26
44,1
$\geq 12$ penyajian menarik
33
55,9

13. Cara Pemberian Menu

< 24 cara \& waktu pemberian kurang $27 \quad 45,8$

teratur

$\geq 24$ cara \& waktu pemberian teratur

32

54,2

\begin{tabular}{llc}
\hline No. Variabel & Jumlah & Persentase (\%) \\
\hline & FOOD FREQUENCY QUESTIONNAIRE
\end{tabular}

14. Makanan Pokok

$\begin{array}{lll}<4 \text { variasi/hari } & 31 & 52,5 \\ \geq 4 \text { variasi /hari } & 28 & 47,5\end{array}$

15. Lauk Hewani

$\begin{array}{lll}<4 \text { variasi/hari } & 29 & 49,2 \\ \geq 4 \text { variasi /hari } & 30 & 50,8\end{array}$

16. Kacang-kacangan

$\begin{array}{lll}<1 \text { variasi / } 2 \text { hari } & 29 & 49,2 \\ \geq 1 \text { variasi / } 2 \text { hari } & 30 & 50,8\end{array}$

17. Sayur-sayuran

$<2$ variasi / hari

49,2

$\geq 2$ variasi /hari

30

50,8 


\begin{tabular}{|c|c|c|c|}
\hline \multirow[t]{3}{*}{18.} & Buah-buahan & & \\
\hline & $<3$ variasi / hari & 29 & 49,2 \\
\hline & $\geq 3$ variasi /hari & 30 & 50,8 \\
\hline \multirow[t]{3}{*}{19.} & Susu dan Olahan & & \\
\hline & $<3$ variasi / hari & 29 & 49,2 \\
\hline & $\geq 3$ variasi /hari & 30 & 50,8 \\
\hline \multirow[t]{3}{*}{20.} & Jajanan dan Junkfood & & \\
\hline & $<4$ variasi/hari & 32 & 54,2 \\
\hline & $\geq 4$ variasi /hari & 27 & 45,8 \\
\hline \multirow[t]{3}{*}{21.} & Softdrink dan Minuman Manis & & \\
\hline & $<1$ kali/3 bulan & 37 & 62,7 \\
\hline & $\geq 1$ kali/3 bulan & 22 & 37,3 \\
\hline \multirow[t]{3}{*}{22.} & Multivitamin & & \\
\hline & $<1 \mathrm{kali} /$ hari & 12 & 20,3 \\
\hline & 1 kali/hari & 47 & 79,7 \\
\hline \multirow[t]{3}{*}{23.} & Total Konsumsi per/Hari & & \\
\hline & $<21$ variasi/hari & 29 & 49,2 \\
\hline & $\geq 21$ variasi/hari & 30 & 50,8 \\
\hline
\end{tabular}

Tabel 3

Hasil Analisis Bivariat Status Gizi (IMT/U) bulan Juni

\begin{tabular}{|c|c|c|c|c|c|c|}
\hline \multirow[t]{3}{*}{ Variabel } & \multicolumn{4}{|c|}{ Status Gizi (IMT/U) Bulan Juni } & \multirow[t]{3}{*}{ p Value } & \multirow{3}{*}{$\begin{array}{l}\text { OR (Cl } \\
95 \%)\end{array}$} \\
\hline & \multicolumn{2}{|c|}{$\begin{array}{c}\text { Status gizi } \\
\text { kurus-normal }\end{array}$} & \multicolumn{2}{|c|}{$\begin{array}{c}\text { Status gizi } \\
\text { gemuk- } \\
\text { obesitas }\end{array}$} & & \\
\hline & $\mathbf{n}$ & $\%$ & $\mathbf{n}$ & $\%$ & & \\
\hline \multicolumn{7}{|l|}{ Jenis Kelamin } \\
\hline Perempuan & 17 & 56,7 & 10 & 34,5 & 0,147 & - \\
\hline Laki-laki & 13 & 43,3 & 19 & 65,5 & & \\
\hline \multicolumn{7}{|l|}{ Usia Ibu } \\
\hline$<36.10$ tahun & 20 & 66,7 & 14 & 48,3 & 0,153 & - \\
\hline$\geq 36.10$ tahun & 10 & 33,3 & 15 & 51,7 & & \\
\hline
\end{tabular}




\begin{tabular}{|c|c|c|c|c|c|c|}
\hline Pendidikan Ibu & & & & & & \\
\hline SMA kebawah & 6 & 20 & 10 & 34,5 & 0,211 & - \\
\hline Perguruan Tinggi & 24 & 80 & 19 & 65,5 & & \\
\hline \multicolumn{7}{|l|}{ Jumlah anak } \\
\hline$>2$ anak & 2 & 6,7 & 2 & 6,9 & 0,972 & - \\
\hline$\leq 2$ anak & 28 & 93,3 & 27 & 93,1 & & \\
\hline \multicolumn{7}{|c|}{ Jumlah Anggota keluarga } \\
\hline$>4$ anggota keluarga & 6 & 20 & 7 & 24,1 & 0,945 & - \\
\hline$\leq 4$ anggota keluarga & 24 & 80 & 22 & 75,9 & & \\
\hline \multicolumn{7}{|l|}{ ASI Eksklusif } \\
\hline$<6$ bulan & 14 & 46,7 & 6 & 20,7 & 0,067 & - \\
\hline$\geq 6$ bulan & 16 & 53,3 & 23 & 79,3 & & \\
\hline \multicolumn{7}{|c|}{ Anak Sakit (Januari-Juni) } \\
\hline Ya & 2 & 6,7 & 3 & 10,3 & 0,612 & - \\
\hline tidak & 28 & 93,3 & 26 & 89,7 & & \\
\hline \multicolumn{7}{|l|}{ Pengetahuan Ibu } \\
\hline$<80 \%$ & 19 & 63,3 & 9 & 31,0 & 0,026 & 3,838 \\
\hline \multirow[t]{2}{*}{$\geq 80 \%$} & 11 & 36,7 & 20 & 69,0 & & $(1,301-$ \\
\hline & & & & & & $11,323)$ \\
\hline
\end{tabular}

POLA PEMBERIAN MAKAN

\section{Cara Penyusunan Menu}

$<13$ (Kurang variatif)

$\begin{array}{cccccc}19 & 63,3 & 9 & 31,0 & 0.026 & 3,838 \\ 11 & 36,7 & 20 & 69,0 & & (1,301-\end{array}$

$\geq 13$ (makanan bervariasi)

11,323)

\begin{tabular}{|c|c|c|c|c|c|}
\hline \multicolumn{6}{|l|}{ Cara Olah Menu } \\
\hline$<13$ (kurang menjaga & 14 & 46,7 & 7 & 24,1 & 0,125 \\
\hline \multicolumn{6}{|l|}{ kualitas olahan makanan) } \\
\hline$\geq 13$ baik dalam menjaga & 16 & 53,3 & 22 & 75,9 & \\
\hline
\end{tabular}

\section{Cara Saji Menu}

$\begin{array}{llllll}<12 \text { penyajian monoton } & 17 & 56,7 & 9 & 31,0 & 0,085 \\ \geq 12 \text { penyajian menarik } & 13 & 43,3 & 20 & 69,0 & \end{array}$




\begin{tabular}{|c|c|c|c|c|c|c|}
\hline \multicolumn{7}{|l|}{ Cara Pemberian Menu } \\
\hline $\begin{array}{l}<24 \text { cara } \& \text { waktu pemberian } \\
\text { kurang teratur }\end{array}$ & 21 & 70 & 6 & 20,7 & $<0,0001$ & $\begin{array}{c}8,944 \\
(2,720-\end{array}$ \\
\hline $\begin{array}{l}\geq 24 \text { cara \& waktu pemberian } \\
\text { teratur }\end{array}$ & 9 & 30 & 23 & 79,3 & & $29,412)$ \\
\hline
\end{tabular}

\section{FOOD FREQUENCY QUESTIONNAIRE}

\begin{tabular}{lcccccc}
\hline Makanan Pokok & & & & & & \\
$<4$ variasi/hari & 21 & 70 & 10 & 34,5 & 0,013 & 4,433 \\
$\geq 4$ variasi/hari & 9 & 30 & 19 & 65,5 & & $(1,485-$ \\
& & & & & & $13,234)$
\end{tabular}

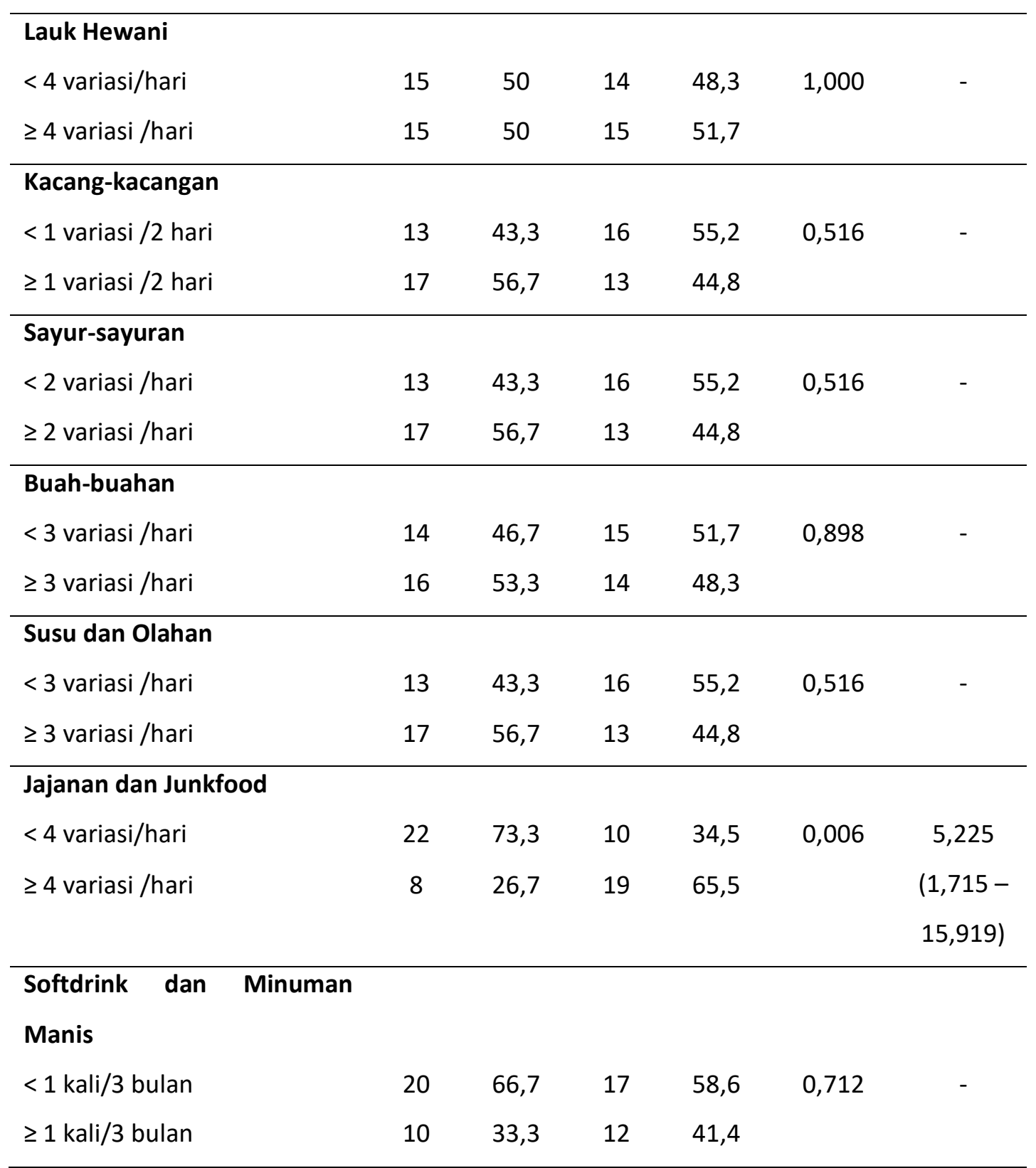




\begin{tabular}{lcccccc}
\hline $\begin{array}{l}\text { Multivitamin } \\
<1 \text { kali/hari }\end{array}$ & 8 & 26,7 & 4 & 13,8 & 0,219 & - \\
1 kali/hari & 22 & 73,3 & 25 & 86,2 & & \\
\hline $\begin{array}{l}\text { Total Konsumsi per/Hari } \\
<21 \text { variasi/hari }\end{array}$ & 16 & 53,3 & 13 & 44,8 & 0,694 & - \\
$\geq 21$ variasi/hari & 14 & 46,7 & 16 & 55,2 & \\
\hline
\end{tabular}

Tabel 4

Hasil Analisis Multivariat Menggunakan Regresi Logistik

\begin{tabular}{|c|c|c|c|c|c|c|c|}
\hline \multirow[t]{2}{*}{ Variabel } & \multirow[t]{2}{*}{$B$} & \multirow[t]{2}{*}{ S.E } & \multirow[t]{2}{*}{ Wald } & \multirow[t]{2}{*}{ Sig } & \multirow[t]{2}{*}{$\operatorname{Exp}(B)$} & \multicolumn{2}{|c|}{$\begin{array}{c}95 \% \mathrm{Cl} \text { for } \\
\operatorname{EXP}(\mathrm{B})\end{array}$} \\
\hline & & & & & & $L$ & $U$ \\
\hline Jenis kelamin & 2.185 & 1.195 & 3.345 & 0,067 & 8,890 & 0,855 & 92,43 \\
\hline Pendidikan ibu & $\begin{array}{c}- \\
2,277\end{array}$ & 1,030 & 4,891 & $* 0,027$ & 0,103 & 0,014 & 0,772 \\
\hline ASI Eksklusif & 0,933 & 0,941 & 0,984 & 0,321 & 2,542 & 0,402 & 16,060 \\
\hline Pengetahuan ibu & $\begin{array}{c}- \\
1,327\end{array}$ & 1,318 & 1,015 & 0,314 & 0,265 & 0,020 & 3,508 \\
\hline $\begin{array}{c}\text { Cara penyusunan } \\
\text { menu }\end{array}$ & 2,626 & 1,077 & 5,943 & $* 0,015$ & 13,818 & 1,673 & 114,11 \\
\hline Cara olah menu & $\begin{array}{c}- \\
1,610\end{array}$ & 1,380 & 1,362 & 0,243 & 0,200 & 0,013 & 2,986 \\
\hline Cara saji menu & 1,002 & 0,911 & 1,210 & 0,271 & 2,723 & 0,457 & 16,227 \\
\hline $\begin{array}{l}\text { Cara pemberian } \\
\text { menu }\end{array}$ & 4,240 & 1,864 & 5,173 & $* 0,023$ & 69,383 & 1,797 & 2678,7 \\
\hline Makanan pokok & 0,428 & 0,872 & 0,241 & 0,623 & 1,534 & 0,278 & 8,471 \\
\hline $\begin{array}{l}\text { Jajanan dan } \\
\text { junkfood }\end{array}$ & 0,791 & 0,974 & 0,660 & 0,417 & 2,206 & 0,327 & 14,877 \\
\hline multivitamin & 0,836 & 1,203 & 0,483 & 0,487 & 2,308 & 0,218 & 24,397 \\
\hline
\end{tabular}

Keterangan: * $p$ value $<0,005$, terdapat hubungan 
Berdasarkan hasil analisis multivariat terdapat 3 variabel yang mempunyai $p$ value $<0,05$ yaitu pendidikan ibu ( $p$ value $=$ $0,027)$, cara penyusunan menu ( $p$ value $=$ $0,015)$, dan cara pemberian menu ( $p$ value $=0,023)$. Variabel cara pemberian menu mempunyai nilai OR yang paling besar yaitu sebesar 69,38, artinya anak yang mempunyai status gizi gemuk-obesitas cenderung senang dengan cara pemberian menu makan yang dibuat oleh ibunya sebesar 69,38 kali dibandingkan dengan anak status gizi kurus-normal begitu juga variabel pendidikan ibu dan cara penyusunan menu setelah dikontrol dengan variabel jenis kelamin, riwayat ASI eksklusif, pengetahuan ibu, cara olah menu, cara saji menu, makanan pokok (sumber karbohidrat), jajanan dan junkfood, dan multivitamin.

Berdasarkan tabel 4 didapatkan bahwa Variabel cara pemberian menu mempunyai nilai $O R$ yang paling besar yaitu sebesar 69,38, artinya anak yang mempunyai status gizi gemuk-obesitas cenderung senang dengan cara pemberian menu makan yang dibuat oleh ibunya sebesar 69,38 kali dibandingkan dengan anak status gizi kurus-normal begitu juga variabel pendidikan ibu dan cara penyusunan menu setelah dikontrol dengan variabel jenis kelamin, riwayat ASI eksklusif, pengetahuan ibu, cara olah menu, cara saji menu, makanan pokok (sumber karbohidrat), jajanan dan junkfood, dan multivitamin.

Cara pemberian makan merupakan variabel dominan dalam penelitian ini. Pernyataan tentang susunan waktu teratur dan porsi yang tepat dalam pemberian makan relevan dengan penelitian yang menjelaskan bahwa komponen utama dari makan sehat untuk balita adalah ketersediaan dan variasi pilihan makanan sehat untuk kudapan dan makanan. Makanan seimbang memiliki porsi dari setidaknya tiga dari empat kelompok makanan, dan makanan ringan seimbang memiliki porsi dari dua dari empat kelompok makanan. ${ }^{10}$ Suka dan tidak suka makanan memainkan peran penting dalam pilihan makanan, terutama pada anakanak. $^{11}$

Seorang anak yang minatnya pada makanan berkembang cukup dini memiliki peluang lebih kecil untuk melewatkan makan. Orang tua atau pengasuh mengembangkan minat anak pada makanan sejak awal kehidupan memiliki kecenderungan untuk meningkatkan penerimaan anak terhadap makanan yang berbeda terutama di tahun-tahun awal sehingga memiliki pola makan yang sehat. $^{12}$

Penting bagi orang tua dan pengasuh untuk memastikan bahwa minat 
anak pada makanan dikembangkan sejak dini karena hal ini akan memastikan bahwa anak tersebut memenuhi asupan makanan yang direkomendasikan dan akan mempengaruhi pertumbuhan dan perkembangan anak secara positif dan meningkatkan status gizi anak. ${ }^{13}$ Selama masa balita, anak mengembangkan kemampuan fisik untuk makan sendiri dan mempelajari ekspektasi sosial, budaya, dan perilaku yang berkaitan dengan makanan. ${ }^{14}$ Pemberian makan sendiri harus didorong karena akan membantu anak mengembangkan keterampilan motorik halus dan akan mengarah pada pengembangan asupan energi yang terkontrol. ${ }^{15}$ Memperkenalkan makanan baru kemungkinan besar hanya akan diterima setelah pemajanan berulang (setidaknya 10 kali), dan anak-anak akan menikmati makanan mereka jika mereka memiliki orang tua/pengasuh yang menyajikan berbagai makanan dan menumbuhkan kemandirian dan kepercayaan diri. ${ }^{16}$

Salah satu pernyataan dalam pola pemberian makan adalah waktu pemberian makanan, struktur kebiasaan makan orang dewasa akan dipelajari pada usia balita dan pra-sekolah. Camilan sehat adalah "makanan kecil" yang penting dalam kebiasaan ini dan disimpan pada ingatan dalam waktu bertahun-tahun.
Orang tua/pengasuh dapat menciptakan lingkungan sosial yang diinginkan seperti dengan duduk di meja, mematikan televisi, dan makan makanan yang sama pada balita di mana pada masa ini kebiasaan gizi yang baik berkembang. ${ }^{17}$

Penyusunan menu berhubungan dengan status gizi beberapa pernyataan tentang komposisi zat gizi dan variasi menu dalam penyusunan menu untuk anak mempunyai relevansi penelitian dengan skor keragaman makanan yang secara signifikan dikaitkan dengan indikator gizi dari stunting dan underweight pada anak usia empat dan lima tahun, masing-masing. Skor keragaman makanan yang lebih tinggi secara signifikan dikaitkan dengan kemungkinan yang lebih rendah untuk mengalami stunting di antara anak-anak berusia empat tahun. ${ }^{18}$ Stunting dimulai pada awal kehidupan seorang anak dan mencerminkan status gizi jangka Panjang. ${ }^{19}$

Berat badan kurang pada anak-anak terutama disebabkan oleh asupan makanan yang tidak memadai ${ }^{20}$, praktik pemberian makan yang buruk ${ }^{21}$ dan praktik pengasuhan anak ${ }^{22}$ di antara faktor-faktor lain, seperti infeksi berulang ${ }^{23}$ ekonomi ${ }^{22}$ tempat tinggal ${ }^{24}$ faktor sosial, dan budaya. ${ }^{25}$ Oleh karena itu, keanekaragaman pangan yang dikonsumsi oleh anak-anak perlu ditingkatkan, guna mengurangi berbagai bentuk gizi buruk. 
Pada hasil penelitian ditemukan bahwa pendidikan Ibu mempunyai hubungan dengan status gizi anak. Dalam penelitian lain ditemukan bahwa pendidikan ibu sering kali memiliki hubungan yang jauh lebih kuat dengan hasil ini daripada pendidikan ayah. Secara khusus, pendidikan ibu memiliki hubungan yang lebih kuat secara signifikan dengan keragaman makanan anak (tetapi bukan keragaman pola makan ibu) pendidikan ibu menunjukkan peran yang lebih kuat untuk pendidikan perempuan dalam mempengaruhi berbagai perilaku yang berhubungan dengan gizi. ${ }^{26}$ Mempertahankan anak perempuan di sekolah lebih lama dapat menunda usia pernikahan dan kelahiran pertama, mengurangi permintaan akan anak, dan memberdayakan perempuan untuk membuat keputusan yang mungkin tidak mereka buat, seperti melahirkan beberapa dan jarak kelahiran yang lebih merata, dan memanfaatkan layanan kesehatan modern dengan lebih baik. ${ }^{27}$

Hasil penelitian sejalan dengan penelitian yang dilakukan Sambo bahwa terdapat hubungan antara pola makan dengan status gizi pada anak usia prasekolah di TK Kristen Tunas Rama. ${ }^{3}$

Penelitian ini juga sejalan dengan penelitian yang dilakukan oleh Sa'diya bahwa ada hubungan antara pola makan dengan status gizi anak usia prasekolah di PAUD Tunas Mulia Desa Claket Kecamatan Pacet Kabupaten Mojokerto dengan nilai $p$ value $=0,038 .^{7}$

Kecukupan makanan dan kemampuan tubuh yang mengandung zat gizi untuk kesehatan menentuka status gizi. Jika kecukupan konsumsi makanan kurang akan mempermudah timbulnya penyakit yang akan mempengaruhi pertumbuhan dan mengakibatkan status gizi menurun. ${ }^{8}$

Zat gizi memiliki keterkaitan yang erat hubungan dengan kesehatan dan kecerdasan dan juga tumbuh kembang anak. Jika pola makan tidak tercapai dengan baik pada anak usia prasekolah maka masa pertumbuhan akan terganggu. Sehingga dapat menyebabkan tubuh kurus, pendek, bahkan bisa terjadi gizi buruk pada anak usia prasekolah. Pola makan pada anak usia prasekolah berperan penting dalam proses pertumbuhan pada anak usia prasekolah, karena dalam makanan banyak mengandung zat gizi. ${ }^{9}$

\section{KESIMPULAN DAN SARAN \\ KESIMPULAN}

Cara pemberian makan, cara penyusunan menu, dan Pendidikan ibu merupakan prediktor dari status gizi anak prasekolah. Pemberian makan, penyusunan menu yang tepat, dan Pendidikan tinggi pada ibu menjadi arah untuk mengetahui dan 
mengaplikasikan aneka ragam makanan yang sesuai dengan kebutuhan gizi anak untuk membantu pencapaian gizi yang seimbang pada anak.

\section{SARAN}

1. Diharapkan bagi ibu untuk mengikuti penyuluhan tentang status gizi Anak

2. Sekolah bekerjasama dengan pihak puskesmas setempat untuk dilakukan promosi atau edukasi tentang gizi pada anak prasekolah.

\section{DAFTAR PUSTAKA}

1. Sulistyawati, A. (2015). Deteksi Tumbuh Kembang Anak. Jakarta: Salemba Medika

2. Rahardjo, S., Wayanti, S., \& Wardani, N. E. K. (2019). Pengaruh Fungsi Manajemen Pelaksana Kegiatan SDITK terhadap Cakupan SDITK Balita \& Anak Prasekolah. Jurnal Pamator, 12(1). https://doi.org/http://dx.doi.org/10.2 1107/pmt.v12i1.5173http://repository .usu.ac.id/handle/1 23456789/32433

3. Sambo, Mery. Dkk. 2020. Hubungan Pola Makan Dengan Status Gizi Pada Anak Usia Prasekolah. Jurnal IImiah Kesehatan Sandi Husada. hhttps://akper-sandikarsa.ejournal.id/JIKSH. Vol 11, No, 1, Juni 2020, pp;423-429, p-ISSN: 2354-6093 dan e-ISSN: 2654-4563.DOI: 10.35816/jiskh.v10i2.316

4. Sari, Milda Riski Nirmala. Dkk. 2018. Hubungan Pengetahuan lbu tentang Pola Pemberian Makan dengan Status Gizi Balita di Wilayah Kerja Puskesmas Gapura Kabupaten Sumenep Relation. Jurnal Amerta Nutrition (2018) 182188 $\mathrm{DOI}$ 10.2473/amnt.v2i2.2018.182-188

5. Rinowanda, Syella Aprilia. Dkk. 2019. Hubungan Pengetahuan Gizi dan Pola Asuh Keluarga dengan Status Gizi Anak Prasekolah di TK Negeri Pembina 1 Kota Tangerang Selatan 2018. Jurnal Ilmiah Kesehatan Masyarakat Vol. 11 Edisi 1, 2019. Fakultas Ilmu Kesehatan, Universitas Pembangunan Nasional Veteran Jakarta.

6. Supariasa., Bakrie, B., Fajar, I. (2012). Penilaian Status Gizi. Jakarta: EGC

7. Sa'diya, Lida Khalimatus. 2015. Hubungan Pola Makan Dengan Status Gizi Anak Pra Sekolah Di Paud Tunas Mulia Claket Kecamatan Pacet Mojokerto. Jurnal Midwiferia Vol. 1 No.2 Oktober 2015.

8. Soetjiningsih., Ranuh. (2015). Tumbuh Kembang Anak. Jakarta: EGC

9. Proverawati, A 2009. Buku Ajar Gizi Untuk Kebidanan. Yogyakarta: Nuha Medika 
10. Leann Lipps Birch Mary Deysher. (1985). Conditioned and unconditioned caloric compensation: Evidence for self-regulation of food intake in young children. Learning and Motivation, Volume 16(Issue 3), Pages 341-355.

https://doi.org/https://doi.org/10.101 6/0023-9690(85)90020-7

11. Scaglioni S, Arrizza C, Vecchi F, T. S. D. of children's eating behavior. A. J. C. N. 2011 D. S.-2011S. doi: 10. 3945/ajcn. 110. 001685. E. 2011 N. 16. P. 22089441. (2011). Determinants of children's eating behavior. Epub 2011 Nov 16., Scaglioni. https://doi.org/10.3945/ajcn.110.001 685.

12. Mary, O. O., Jerffson, O. K., \& Abiodun, O. J. (2019). Nutritional status and eating patterns of preschool children in a community in south-west Nigeria. Nigerian Journal of Nutritional Sciences, 40(2), 30-37.

13. Riley, L. K., Rupert, J., \& Boucher, O. (2018). Nutrition in toddlers. American Family Physician, 98(4), 227-233.

14. Niinikoski, H., Lapinleimu, H., Viikari, J., Rönnemaa, T., Jokinen, E., Seppänen, R., Terho, P., Tuominen, J., Välimäki, I., \& Simell, O. (1997). Growth until 3 years of age in a prospective, randomized trial of a diet with reduced saturated fat and cholesterol. Pediatrics, 99(5), 687694.

https://doi.org/10.1542/peds.99.5.68 7

15. Butte, N. F. (2000). Fat intake of children in relation to energy requirements. American Journal of Clinical Nutrition, 72(5 SUPPL.), 12461252.

https://doi.org/10.1093/ajcn/72.5.124 $6 s$

16. Sullivan, S. A., \& Birch, L. L. (1990). Pass the sugar, pass the salt: Experience dictates preference. Developmental Psychology, 26(4), 546-551.

https://doi.org/https://doi.org/10.103 7/0012-1649.26.4.546

17. E. Satter. (1988). How to get your kid to eat - but not too much. Molecular Nutrition Food Research, volume 32(Issue 923 9), https://doi.org/https://doi.org/10.100 2/food.19880320927

18. Modjadji, P., Molokwane, D., \& Ukegbu, P. O. (2020). Dietary Diversity and Nutritional Status of Preschool Children in North West Province, South Africa: A Cross Sectional Study. Children, $\quad 7(10), \quad 174$. https://doi.org/10.3390/children 7100 174 
19. de Onis, M., \& Branca, F. (2016). Childhood stunting: A global perspective. Maternal and Child Nutrition, 12, 12-26. https://doi.org/10.1111/mcn.12231

20. Batis, C., Aburto, T. C., SánchezPimienta, T. G., Pedraza, L. S., \& Rivera, J. A. (2016). Adherence to dietary recommendations for food group intakes is low in the Mexican population. Journal of Nutrition, 146(9), 1897S-1906S. https://doi.org/10.3945/jn.115.21962 6

21. Campbell, R. K., Hurley, K. M., Shamim, A. A., Shaikh, S., Chowdhury, Z. T., Mehra, S., De Pee, S., Ahmed, T., West, K. P., \& Christian, P. (2016). Effect of complementary food supplementation on breastfeeding and home diet in rural Bangladeshi children. American Journal of Clinical Nutrition, 104(5), 1450-1458. https://doi.org/10.3945/ajcn.116.135 509

22. Negash, C., Whiting, S. J., Henry, C. J., Belachew, T., \& Hailemariam, T. G. (2015). Association between maternal and child nutritional status in Hula, rural Southern Ethiopia: A cross sectional study. PLOS ONE, 10(11), 18. https://doi.org/10.1371/journal.pone. 0142301

23. Abdi, M., Nibret, E., \& Munshea, A. (2017). Prevalence of intestinal helminthic infections and malnutrition among schoolchildren of the Zegie Peninsula, northwestern Ethiopia. Journal of Infection and Public Health, 10(1), 84-92. https://doi.org/10.1016/j.jiph.2016.02 .009

24. Humphries, D. L., Dearden, K. A., Crookston, B. T., Woldehanna, T., Penny, M. E., \& Behrman, J. R. (2017). Household food group expenditure patterns are associated with child anthropometry at ages 5, 8 and 12 years in Ethiopia, India, Peru and Vietnam. Economics and Human Biology, 26, 30-41. https://doi.org/10.1016/j.ehb.2017.02 .001

25. Bliss, J. R., Njenga, M., Stoltzfus, R. J., \& Pelletier, D. L. (2016). Stigma as a barrier to treatment for child acute malnutrition in Marsabit County, Kenya. Maternal and Child Nutrition, 12(1), 125-138. https://doi.org/10.1111/mcn.12198

26. Alderman, H., \& Headey, D. D. (2017). How Important is Parental Education for Child Nutrition? World Development, $\quad 94, \quad 448-464$. 
https://doi.org/10.1016/j.worlddev.20

17.02.007

27. Lassi, Z. S., Das, J. K., Zahid, G., Imdad, A., \& Bhutta, Z. A. (2013). Impact of education and provision of complementary feeding on growth and morbidity in children less than 2 years of age in developing countries: $A$ systematic review. BMC Public Health, 13(SUPPL.3), 1-10. https://doi.org/10.1186/1471-245813-S3-S13 